\title{
Identification of polymorphisms in human interleukin-27 and their association with asthma in a Korean population
}

\author{
Soo-Cheon Chae $\cdot$ Chun-Shi Li $\cdot$ Ki Mo Kim • \\ Ji Yeon Yang · Qinggao Zhang · Yong-Chul Lee • \\ Yun-Sik Yang $\cdot$ Hun-Taeg Chung
}

Received: 13 December 2006/ Accepted: 27 January 2007/Published online: 22 February 2007

(C) The Japan Society of Human Genetics and Springer 2007

\begin{abstract}
Interleukin 27 (IL-27) acts as a versatile cytokine in the early regulation of Th1 initiation and in the negative regulation of the Th2 factor GATA-3. IL27, which was discovered as a novel heterodimeric cytokine of the IL-12 family, consists of two subunits, the Epstein-Barr virus-induced gene 3 (EBI3) and p28. The IL-27 cytokine is mediated by one of the receptor
\end{abstract}

S.-C. Chae and C.-S. Li contributed equally to this work

S.-C. Chae · K. M. Kim · J. Y. Yang · H.-T. Chung ( $ه)$

Genome Research Center for Immune Disorders,

Wonkwang University School of Medicine, Iksan,

Chonbuk 570-749, South Korea

e-mail: htchung@wonkwang.ac.kr

C.-S. Li · H.-T. Chung

Department of Microbiology and Immunology,

Wonkwang University School of Medicine,

Iksan, Chonbuk 570-749, South Korea

C.-S. Li

Department of Pharmacology,

Yanbian University Medical College,

Yianji, Jilin, China

\section{Q. Zhang}

Department of Microbiology and Immunology,

Yanbian University Medical College,

Yianji, Jilin, China

\section{Y.-C. Lee}

Department of Internal Medicine,

Research Center for Allergic Immune Diseases,

Chonbuk National University Medical School,

Chonju, Chonbuk, South Korea

\section{Y.-S. Yang}

Department of Ophthalmology,

Wonkwang University School of Medicine,

Iksan, Chonbuk 570-749, South Korea chains (WSX-1) of the IL-27 receptor that is highly expressed on $\mathrm{CD}^{+}{ }^{+} \mathrm{T}$ lymphocytes and NK cells. Although signaling of IL-27/WSX-1 interactions have been recognized in the down-regulation of airway hyper-reactivity and in lung inflammation during the development of allergic asthma, little is known about the role of single nucleotide polymorphisms (SNPs) of IL-27 and individual susceptibility to asthma. To address this question, we have examined the five exons and the boundary intron sequences of $I L-27 P 28$, including the promoter regions, with the aim of identifying sites of variation that may be useful for understanding the genetic influences of this gene. We identified four SNPs, g.-964A $>$ G, g.2905T $>$ G, g. $4603 \mathrm{G}>\mathrm{A}$ and g.4730T $>\mathrm{C}$, and analyzed the genotype and allele frequencies between asthma patients and healthy controls. Our results strongly suggest that the g.-964A $>\mathrm{G}$ polymorphism of $I L-27 p 28$ is most likely associated with susceptibility to asthma. Moreover, we elucidate the haplotype frequencies of g.2905T > G, g.4603G > A and g.4730T > C in terms of their relative correlation with asthma patients and healthy controls.

Keywords Asthma - Haplotype $\cdot I L-27$.

Polymorphism $\cdot$ Th cell

\section{Introduction}

Asthma is one of the most common multi-complex disorders triggered by the interaction of genetic predisposition and environmental factors (Cookson 2002). Unlike other inflammatory diseases, the asthmatic inflammatory process is characterized by the predom- 
inant secretion of Interleukin (IL)-4 and IL-5 by Thelper lymphocyte type 2 (Th2) cells and immunoglobulin $\mathrm{E}(\mathrm{IgE})$ synthesis. $\mathrm{IgE}$ has been shown to mediate both early and late asthmatic responses in an induction of lung eosinophil infiltration and Th2 cell cytokine production (Coyle et al. 1996). Mast cells are activated independent of $\mathrm{IgE}$, while eosinophils and basophils are recruited into the site of the allergic reaction (Daser et al. 1995; O'Garra 1998). The accumulation of eosinophils is an important characteristic feature in the pathogenesis of asthma because it accompanied by inflammation within the bronchial wall (Humbles et al. 1997).

In general, naive $\mathrm{T}$ helper cells are differentiated into Th1 or Th2 cells depending on multiple influences by cytokines, types of antigen, transcription factors and signaling pathways (Ho and Glimcher 2002). However, genetic polymorphisms may be one of the more crucial factors that predispose to the imbalance between Th1 and Th2 cells. Interestingly, Th1 and Th2 cells crossregulate the differentiation of partner subset, which suggests that the stimulation of Th1 cells could suppress Th2 cells and the allergic inflammation. On the other hand, the predominant induction of Th2 cells inhibits autoimmune diseases, while the induction of Th1 cells regulates the induction of asthma and allergic diseases (Hofstra et al. 1998; Lack et al. 1994).

IL-12 is regarded as playing a central role in the early differentiation of naive $\mathrm{T}$ cells into those with the Th1 phenotype. Furthermore, the cytokine is a strong inducer of interferon gamma (IFN- $\gamma$ ) production and promotes a protective cell-mediated immune response in the case of Mycobacterium tuberculosis infection (Cooper et al. 1997). IL-27 has only recently been determined to be a novel heterodimeric cytokine of the IL-12 family. This molecule is composed of two subunits. One is a soluble type I cytokine receptor-like molecule that is coded by the Epstein-Barr virus (EBV)induced gene 3 (EBI3); this subunit has sequence homology with IL-12p40 (Devergne et al. 1996). The other subunit is p28 (Pflanz et al. 2002). Structurally, the heterodimeric IL-27p28 chain belongs to the family of long-chain four-helix bundle cytokines and displays sequence homology to IL-12p35 and IL-23p19 (Pflanz et al. 2002). EBI3 and p28 are highly co-expressed in activated tumor-suppressor gene products called adenomatous polyposis coli (APCs)(Pflanz et al. 2002; Wirtz et al. 2005). The IL-27 receptor (IL-27R) is composed of the class I cytokine receptor chain WSX-1 (also known as TCCR) and the cytokine IL-6-related gp130 chain (Pflanz et al. 2004; Sprecher et al. 1998). The biological effects of IL-27 are mediated by the WSX-1 that is highly expressed on $\mathrm{CD} 4^{+} \mathrm{T}$ lymphocytes and NK cells.
IL-27 is known to play multiple roles in the up-regulation of Th1 initiation as well as in the down-regulation of Th2 factor Gata binding protein 3 (GATA-3). In comparison with wild-type mice, WSX-1 $1^{(--)}$mice manifest significantly increased levels of airway immune response and serum IgE with infiltration of the pulmonary eosinophil, indicating that IL-27 and WSX-1 have a function in the down-regulation of airway hyper-reactivity and lung inflammation during the development of allergic asthma (Miyazaki et al. 2005). The dissociated expression of EBI3 and p28 in transformed cells suggests that EBI3 may play a role - independent of its association with p28 - in the regulation of anti-viral and anti-tumoral responses (Larousserie et al. 2005).

Although, $I L-27 p 28$ is one of the crucial candidate genes for the development and differentiation of $\mathrm{T}$ cells, a correlation between single nucleotide polymorphisms (SNPs) of IL-27p28 and individual susceptibility of asthma have been only poorly demonstrated. In an attempt to gain a better understanding of the genetic influences of $I L-27 p 28$ on asthma, we have identified the possible variation sites and SNPs in the five exons and their boundary intron sequences of $I L$ $27 P 28$ (that include the approx. $1.9-\mathrm{kb}$ promoter regions). Secondly, to determine whether these $I L-27 P 28$ SNPs are associated with susceptibility to asthma, we have analyzed their frequencies on genomic DNAs isolated from asthma patients and healthy controls. Finally, we have investigated the relationships between individual asthma patients and the polymorphisms by measuring total serum IgE levels and by counting peripheral blood eosinophil numbers.

\section{Materials and methods}

\section{Patients and DNA samples}

With the approval of the review board of the School of Medicine, Wonkwang University and the informed consent of the participants in the study, we obtained blood samples from 288 asthma patients (150 males and 138 females) and 444 healthy non-asthma controls (278 males and 166 females). The mean ages of asthma patients and healthy controls were about 53 and 49 years, respectively. Genomic DNA was extracted from leukocytes of peripheral blood by a standard phenol-chloroform method or by means of a Genomic DNA Extraction kit (iNtRON Biotechnology, Korea) according to the manufacturer's directions. The asthma (atopic and non-atopic) patients were recruited from our outpatient clinic at Chonbuk National University Hospital. Asthma was diagnosed in accordance with 
the criteria of the American Thoracic Society (American Thoracic Society 1987). The healthy controls were recruited from the general population and had undergone a comprehensive medical screening at the Wonkwang University Hospital. All subjects employed in this study were Korean living in the same area. Blood eosinophil counts and total serum IgE levels in asthma patients were measured at the Department of Hematology of Chonbuk National University Hospital, using a Coulter GenSTM Hematology Analyzer (Florida, USA) and Roche COBAS-CORE II (Roche Diagnostics, Basal, Switzerland), respectively.

Polymerase chain reaction (PCR) and sequencing analysis

The entire coding regions of $I L-27 P 28$, including the 1.9-kb promoter regions, were partially amplified with using the GeneAmp PCR System 9700 thermocycler (PE Applied Biosystems, Foster City, Calif.) and three primer pairs (Table 1). The PCR was carried out in a total reaction volume of $20 \mu \mathrm{l}$ containing $50 \mathrm{ng}$ genomic DNA, $0.5 \mu M$ primers, $0.2 \mathrm{~m} M$ dNTP, $1.5 \mathrm{~m} M$ $\mathrm{MgCl}_{2}, 10 \mathrm{mM}$ Tris-HCl (pH 8.3) and $1 \mathrm{U}$ EF Taq polymerase (Solgent, Korea). The reactions were carried out at $94^{\circ} \mathrm{C}$ for $5 \mathrm{~min}$, followed by 30 cycles at $98^{\circ} \mathrm{C}$ for $10 \mathrm{~s}$, at $68^{\circ} \mathrm{C}$ for $30 \mathrm{~s}$ and at $72^{\circ} \mathrm{C}$ for $2 \mathrm{~min}$. The final extension was completed at $68^{\circ} \mathrm{C}$ for $7 \mathrm{~min}$. After purification using a PCR purification kit (Millipore, Bedford, Mass.), the PCR products were used as a template DNA for sequencing analysis (ABI Prism BigDye Terminator cycle sequencing system; ABI 3100 automatic sequencer, PE Applied Biosystems). The sense and antisense strands of PCR products were sequenced directly. The same primers (Table 1) were used as sequencing primers. For the sequencing of the promoter region, five additional primers were em- ployed (Table 1). The SNPs of $I L-27 P 28$ were detected by sequence analysis that was based on the reference sequence of human chromosome 16 clone CIT987SKA-575C2 (AC138894; U95740).

\section{Single-base extension (SBE)}

Genotyping (for g.-964A $>\mathrm{G}$, g.2905T $>\mathrm{G}$ and g.4730T $>\mathrm{C}$ in the $I L-27 P 28$ gene) was performed by SBE with ABI Prism SNaPshot Multiplex kit (Applied Biosystems). The PCR products purified using the PCR Purification kit (Millipore) were used as the template DNA for three SBE primers (Table 1). The SBE reaction mix was prepared according to a previously described method (Chae et al.2005). The primer extension reaction was performed at $96^{\circ} \mathrm{C}$ for $1 \mathrm{~min}$, followed by 25 cycles at $96^{\circ} \mathrm{C}$ for $10 \mathrm{~s}, 55^{\circ} \mathrm{C}$ for $40 \mathrm{~s}$ and $60^{\circ} \mathrm{C}$ for $30 \mathrm{~s}$. To clean up the primer extension reaction, we added $1 \mathrm{U}$ of calf intestinal alkaline phosphatase (CIP; New England BioLabs, Beverly, Mass.) to the reaction mixture and thenincubated the latter at $37^{\circ} \mathrm{C}$ for $60 \mathrm{~min}$. The extension reaction was terminated at $72^{\circ} \mathrm{C}$ for $15 \mathrm{~min}$. The purified extension products were added to $\mathrm{Hi}-\mathrm{Di}$ formamide (Applied Biosystems) and incubated at $95^{\circ} \mathrm{C}$ for $5 \mathrm{~min}$, followed by $5 \mathrm{~min}$ on ice and then electrophoresis on an ABI Prism 3100 Genetic Analyzer. ABI Prism GeneScan and Genotyper software (Applied Biosystems) were used to analyze the sequencing results.

\section{Statistic analysis}

The $\chi^{2}$ tests were applied to estimate the HardyWeinberg equilibrium (HWE). Pair-wise comparison of biallelic loci was employed for the analyses of Linkage Disequilibrium (LD). The haplotype frequencies of $I L-27 P 28$ for multiple loci were estimated using the expectation maximization (EM) algorithm

Table 1 Primer sequences for amplification, sequence analysis and genotyping of the $I L-27 p 28$ gene, including the promoter regions

\begin{tabular}{|c|c|c|c|}
\hline Application & Primer & Primer sequence $\left(5^{\prime} \rightarrow 3^{\prime}\right)$ & Regions \\
\hline \multirow[t]{6}{*}{ PCR analysis } & IL27-PF1 & ACCTCAAGTGATCCACCCGCCT & \multirow[t]{2}{*}{ Promoter and Exon 1} \\
\hline & IL27-PR1 & ATGCAGCAGCCAGCCGAATCCT & \\
\hline & IL27-PF2 & AGTGCCTGCACCGTGCTCACA & \multirow[t]{2}{*}{ Exon 2, 3 and 4} \\
\hline & IL27-PR2 & САСТСТСАСАСТСАСАСАСАСТСА & \\
\hline & IL27-PF3 & ACCTTGTGGTCACTGATGTCA & \multirow[t]{2}{*}{ Exon 5} \\
\hline & IL27-PR3 & GAAGAGCCCTCCCTTGTCCA & \\
\hline \multirow[t]{5}{*}{ Sequencing analysis } & IL27-SF1 & AGAGGAAACAGGGGCTGGACT & Promoter \\
\hline & IL27-SF2 & GTTGAGCCCTGATCCTGACCT & Promoter \\
\hline & IL27-SF3 & СТССААТСССАСССТСАСGСТ & Promoter \\
\hline & IL27-SR1 & ССТTCСТGCTCTCTGCСТCСТ & Promoter \\
\hline & IL27-SR2 & CTGATTCTCGGCTCTGCCACCA & Promoter \\
\hline \multirow[t]{3}{*}{ Single base extension } & IL27-SE1 & AGCCCTGATCCTGACCTCACTCAACTC & g. $-964 \mathrm{~A}>\mathrm{G}$ \\
\hline & IL27-SE2 & GGAGTTCACAGTCAGCCTGCATCTCGCCAGGAAGCTGCTC & g. $2905 \mathrm{~T}>\mathrm{G}$ \\
\hline & IL27-SE3 & GCTTCATCTCCACCACGCTTCAGCCCTTCCATGCCC & g. $4730 \mathrm{~T}>\mathrm{C}$ \\
\hline
\end{tabular}


with SNPALYZE software (DYNACOM, Japan). Logistic regression analyses were adapted to calculate odds ratios $(95 \%$ confidence interval). For statistic analysis, the ANOVA method was applied to define IgE levels of each genotype and to count the number of peripheral blood eosinophil from individual asthma patients. A $P$ value of less than 0.05 was considered to indicate statistical significance.

\section{Results}

The cytokine IL-27, which is composed of two subunits, EBI3 and p28, is a novel IL-12 family member that functions in the differentiation of Th1 cells. Human $I L$ $27 p 28$ is located on chromosome $16 \mathrm{p} 11$ and consists of five exons. To determine possible sites of variation in the entire coding regions and the boundary intron sequences of $I L-27 p 28$, including the approx. 1.9-kb promoter regions, we first scanned the genomic DNAs isolated from 32 unrelated controls. We identified, using a direct sequencing method, four SNPs, g.964A > G (rs153109), g.2905T > G, g.4603G > A (rs181207) and g.4730T > C (rs181206) (Fig. 1). The novel SNPs g.2905T $>\mathrm{G}$ and g.4730T $>\mathrm{C}$ are located on exon 2 and exon 4, respectively, and a single nucleotide transition $\mathrm{T}$ to $\mathrm{G}$ at g.2905T $>\mathrm{G}$ and $\mathrm{T}$ to $\mathrm{C}$ at g.4730T $>\mathrm{C}$ resulted in an amino acid change to p.Ser59Ala and p.Leu119Pro, respectively. LD coefficients $\left(\left|D^{\prime}\right|\right)$ between all SNP pairs were calculated and the absolute $\mathrm{LD}\left(\left|\mathrm{D}^{\prime}\right|=1\right.$ and $\left.r^{2}=1\right)$ was found between g.4603G $>$ A and g.4730T $>C$ (data not shown). Among the polymorphisms identified in this study, three SNPs (g.-964A $>$ G, g.2905T > G and g.4730T > C) were selected for large sample genotyping based on locations, LDs and frequencies.

We then analyzed the genotype of these SNPs on asthma patients and non-asthmatic controls by the SBE method. The genotype and allele frequencies were compared between these groups (Table 2). The genotype frequencies of all loci were in HWE $(P>0.05$, data not shown). The genotype and allele frequencies of g.2905T > G and g.4730T > C were not significantly different between asthma patients and controls. However, in asthma patients, the genotype and allele frequencies of g.-964A $>\mathrm{G}$ of $I L-27 p 28$ were significantly different from those of the control groups $(P=0.006$ and 0.003 , respectively). We further analyzed the genotype and allele frequencies of the SNPs in atopic asthma and non-atopic asthma patients and in healthy controls (Table 3). The genotype and allele frequencies of the g.-964A > G SNP in both atopic and nonatopic asthma patients were significantly different from those in healthy control group (genotype frequencies: $P=0.013$ and 0.022 , respectively; allele frequencies: $P=0.012$ and 0.006 , respectively).

The results of association analysis between genotypes (of individual asthma patients) indicate that these SNPs of $I L-27 p 28$ are not considerably linked with the levels of total serum $\operatorname{IgE}$ and with peripheral blood eosinophil count (Table 4). In both asthma patients and controls, the haplotype frequencies of g.964A > G, g.2905T > G and g.4730T > C of $I L-27 p 28$ were calculated and compared (Table 5). Four major haplotypes were identified that explained more than 95.0 and $94.7 \%$ of the distribution in the controls and asthma patients, respectively, out of eight possible haplotypes. The distribution rate of the two haplotypes ATT and GGT was notably different between the asthma patients and controls $(P<0.035)$.

\section{Discussion}

Developing activated Th cells differentiate into phenotypically and functionally two distinct types of cells,

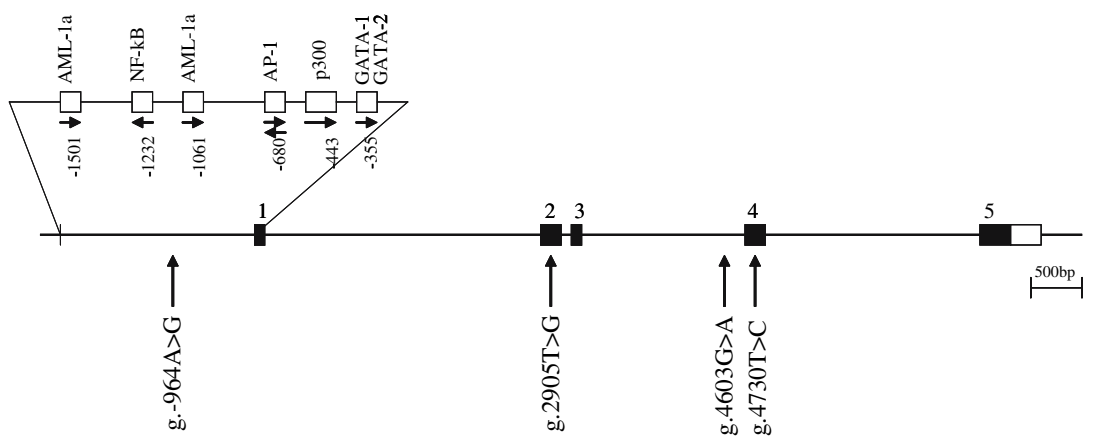

Fig. 1 Locations of each single nucleotide polymorphism (SNP) and sites of variation in $I L-27 p 28$. Coding exons are marked by filled blocks and 3'-untranslated regions (UTR) by open blocks. The positions of SNPs were calculated from the translation start site. Putative transcription factor sites were searched at http:// www.cbrc.jp/research/db/TFSEARCH.html. The reference sequence for $I L-27 p 28$ was based on the sequence of human chromosome 16 clone CIT987SK-A-575C2 (AC138894; U95740) 
Table 2 Genotype and allele analyses of polymorphisms of the $I L-27 p 28$ gene in asthma patients and controls

\begin{tabular}{|c|c|c|c|c|c|}
\hline Position $^{a}$ & Genotype/allele & Control $^{\mathrm{b}}$ & Asthma $^{\mathrm{b}}$ & Odds $\operatorname{ratio}^{c}(95 \% \mathrm{CI})$ & $P^{\mathrm{d}}$ \\
\hline \multirow[t]{5}{*}{ g.-964A > G (rs153109) } & AA & $216(48.6)$ & $175(60.8)$ & 1.00 & \multirow[t]{3}{*}{0.006} \\
\hline & $\mathrm{AG}$ & $190(42.8)$ & $94(32.6)$ & $0.61(0.45-0.84)$ & \\
\hline & GG & $38(8.6)$ & $19(6.6)$ & $0.62(0.34-1.11)$ & \\
\hline & A & $622(70.0)$ & $444(77.1)$ & 1.00 & \multirow[t]{2}{*}{0.003} \\
\hline & G & $266(30.0)$ & $132(22.9)$ & $0.70(0.55-0.89)$ & \\
\hline \multirow[t]{5}{*}{ g. $2905 \mathrm{~T}>\mathrm{G}$} & TT & $343(80.0)$ & $231(83.4)$ & 1.00 & \multirow[t]{3}{*}{0.492} \\
\hline & TG & $79(18.4)$ & $43(15.5)$ & $0.81(0.54-1.21)$ & \\
\hline & GG & $7(1.6)$ & $3(1.1)$ & $0.64(0.16-2.49)$ & \\
\hline & $\mathrm{T}$ & $765(89.2)$ & $505(91.2)$ & 1.00 & \multirow[t]{2}{*}{0.240} \\
\hline & $\mathrm{G}$ & $93(10.8)$ & $49(8.8)$ & $0.80(0.56-1.15)$ & \\
\hline \multirow[t]{5}{*}{ g.4730T > C (rs181206) } & TT & $336(77.6)$ & $225(81.2)$ & 1.00 & \multirow[t]{3}{*}{0.464} \\
\hline & $\mathrm{TC}$ & $96(22.2)$ & $51(18.4)$ & $0.79(0.54-1.16)$ & \\
\hline & $\mathrm{CC}$ & $1(0.2)$ & $1(0.4)$ & $1.49(0.09-24.0)$ & \\
\hline & $\mathrm{C}$ & $768(88.7)$ & $501(90.4)$ & 1.00 & \multirow[t]{2}{*}{0.332} \\
\hline & $\mathrm{T}$ & $98(11.3)$ & $53(9.6)$ & $0.83(0.58-1.18)$ & \\
\hline
\end{tabular}

a Calculated from the translation start site

b Values are given as the number $(n)$ followed by the percentage in parenthesis

${ }^{c}$ Logistic regression analyses were used for calculating the odds ration (OR). The $95 \%$ confidence interval is given in parenthesis

d Value was determined by Fisher's exact test or $\chi^{2}$ test from a $2 \times 2$ contingency table

Table 3 Genotype and allele analyses of the polymorphisms of $I L-27 p 28$ gene in atopic or non-atopic asthma patients and controls

a Calculated from the translation start site

b Values are given as the number $(n)$ followed by the percentage in parenthesis

c Value was determined by Fisher's exact test or $\chi^{2}$ test from the $2 \times 2$ contingency table

\begin{tabular}{|c|c|c|c|c|c|c|}
\hline \multirow[t]{2}{*}{ Position $^{a}$} & \multirow[t]{2}{*}{ Genotype } & \multirow[t]{2}{*}{ Control $^{\mathrm{b}}$} & \multicolumn{2}{|l|}{ Asthma $^{\mathrm{b}}$} & \multirow[t]{2}{*}{$P^{\mathrm{c}}$} & \\
\hline & & & Atopic & Non-atopic & & \\
\hline \multirow[t]{5}{*}{ g.- $964 A>G$} & AA & $216(48.6)$ & $56(65.9)$ & $27(69.2)$ & \multirow[t]{3}{*}{0.013} & \multirow[t]{3}{*}{0.022} \\
\hline & $\mathrm{AG}$ & $190(42.8)$ & $23(27.1)$ & $12(30.8)$ & & \\
\hline & GG & $38(8.6)$ & $6(7.0)$ & $0(0.0)$ & & \\
\hline & A & $622(70.0)$ & $135(79.4)$ & $66(84.6)$ & \multirow[t]{2}{*}{0.012} & \multirow[t]{2}{*}{0.006} \\
\hline & $\mathrm{G}$ & $266(30.0)$ & $35(20.6)$ & $12(15.4)$ & & \\
\hline \multirow[t]{5}{*}{ g. $2905 \mathrm{~T}>\mathrm{G}$} & $\mathrm{TT}$ & $343(80.0)$ & 66 (78.6) & $35(89.7)$ & \multirow[t]{3}{*}{0.891} & \multirow[t]{3}{*}{0.301} \\
\hline & TG & $79(18.4)$ & $17(20.2)$ & $4(10.3)$ & & \\
\hline & GG & $7(1.6)$ & $1(1.2)$ & $0(0.0)$ & & \\
\hline & $\mathrm{T}$ & $765(89.2)$ & $149(88.7)$ & 74 (94.9) & \multirow[t]{2}{*}{0.788} & \multirow[t]{2}{*}{0.124} \\
\hline & G & $93(10.8)$ & $19(11.3)$ & $4(5.1)$ & & \\
\hline \multirow[t]{5}{*}{ g. $4730 \mathrm{~T}>\mathrm{C}$} & TT & $336(77.6)$ & $71(84.5)$ & $32(82.1)$ & \multirow[t]{3}{*}{0.347} & \multirow[t]{3}{*}{0.791} \\
\hline & $\mathrm{TC}$ & $96(22.2)$ & $13(15.5)$ & $7(17.9)$ & & \\
\hline & $\mathrm{CC}$ & $1(0.2)$ & $0(0.0)$ & $0(0.0)$ & & \\
\hline & $\mathrm{T}$ & 768 (88.7) & $155(92.3)$ & $71(91.0)$ & \multirow[t]{2}{*}{0.219} & \multirow[t]{2}{*}{0.575} \\
\hline & $\mathrm{C}$ & $98(11.3)$ & $13(7.7)$ & $7(9.0)$ & & \\
\hline
\end{tabular}

Th1 and Th2 (Abbas et al. 1996; Mosmann and Coffman 1989). Th1 cells produce cytokines such as interferon- $\gamma$ (IFN- $\gamma)$ IL-12 and cytotoxic factor lymphotoxin. They are commonly associated with cellmediated immune responses against intracellular pathogens and the induction of organ-specific autoimmune diseases (Abbas et al. 1996; Kuchroo et al. 1995). On the other hand, the Th2 cell-related cytokines IL-4, IL-5 and IL-10 are known to be associated with atopic and allergic diseases. Allergic disorders are usually accompanied by increased levels of $\mathrm{IgG1}$ and $\mathrm{IgE}$ following the activation of eosinophil and mast cells (Hofstra et al. 1998). IL-27 (IL-12-related cytokine) is one of the critical cytokines that functions as a mediator between the innate and adaptive immune system. Macrophages and dendritic cells produce IL-27 within hours of the stimulation triggered by pathogens. The expression rate of the cytokine is an important factor in determining an effective cell-mediated immune response (Becker et al. 2005). IL-27 and WSX-1 play an important role in the down-regulation of airway hyper-reactivity and lung inflammation during the development of allergic asthma through their suppressive effect on cytokine production (Miyazaki et al. 2005). Therefore, we postulated that SNPs of the IL-27 promoter region may be associated with the aggravated symptom of asthma in different individuals because of a lower production of IL-27 than necessary. 
Table 4 Analyses of serum total IgE levels and peripheral blood eosinophil counts among the genotypes of each SNP of $I L-27 p 28$ gene in asthma patients

\begin{tabular}{|c|c|c|c|c|c|c|c|c|c|}
\hline \multirow[t]{2}{*}{ Position $^{a}$} & \multirow[t]{2}{*}{ Genotype } & \multicolumn{3}{|c|}{$\operatorname{IgE}(\mathrm{IU} / \mathrm{ml})$} & \multirow[t]{2}{*}{$P^{\mathrm{c}}$} & \multicolumn{3}{|c|}{ Eosinophil $(\%)^{\mathrm{b}}$} & \multirow[t]{2}{*}{$P^{\mathrm{c}}$} \\
\hline & & $n$ & Mean & $\begin{array}{l}\text { Standard } \\
\text { deviation }\end{array}$ & & $n$ & Mean & $\begin{array}{l}\text { Standard } \\
\text { deviation }\end{array}$ & \\
\hline \multirow[t]{3}{*}{ g. $-964 A>G$} & AA & 165 & 264 & 198 & \multirow[t]{3}{*}{0.70} & 144 & 4.60 & 4.35 & \multirow[t]{3}{*}{0.95} \\
\hline & $\mathrm{AG}$ & 88 & 253 & 198 & & 83 & 4.76 & 4.09 & \\
\hline & GG & 17 & 224 & 161 & & 17 & 4.87 & 6.11 & \\
\hline \multirow[t]{3}{*}{ g.2905T > G } & TT & 221 & 263 & 200 & \multirow[t]{3}{*}{0.88} & 201 & 4.67 & 4.25 & \multirow[t]{3}{*}{0.94} \\
\hline & TG & 41 & 246 & 173 & & 37 & 4.61 & 5.26 & \\
\hline & GG & 3 & 249 & 243 & & 2 & 4.70 & 4.67 & \\
\hline \multirow[t]{3}{*}{ g.4730T > C } & TT & 218 & 262 & 199 & \multirow[t]{3}{*}{0.73} & 194 & 4.55 & 4.45 & \multirow[t]{3}{*}{0.41} \\
\hline & $\mathrm{TC}$ & 47 & 251 & 186 & & 46 & 5.14 & 4.23 & \\
\hline & $\mathrm{CC}$ & 0 & - & - & & 0 & - & - & \\
\hline
\end{tabular}

a Calculated from the translation start site

b Values were determined by the number of eosinophil cells per total cell numbers in acubic millimeter volume

c Values were analyzed by ANOVA

Table 5 The haplotype frequencies in both asthma patients and controls in $I L$ $27 P 28$ polymorphisms

a Values were constructed bythe expectation maximization (EM) algorithm with genotyped SNPs

b Values were analyzed by the permutation test

\begin{tabular}{|c|c|c|c|c|c|}
\hline \multicolumn{3}{|l|}{ Haplotype } & \multicolumn{2}{|c|}{ Frequency $^{\mathrm{a}}$} & \multirow[t]{2}{*}{$P^{\mathrm{b}}$} \\
\hline g.- $-964 A>G$ & g. $2905 \mathrm{~T}>\mathrm{G}$ & g. $4730 \mathrm{~T}>\mathrm{C}$ & Control & Asthma & \\
\hline A & $\mathrm{T}$ & $\mathrm{T}$ & 0.658 & 0.712 & 0.035 \\
\hline G & $\mathrm{T}$ & $\mathrm{T}$ & 0.120 & 0.104 & 0.353 \\
\hline G & $\mathrm{T}$ & $\mathrm{C}$ & 0.091 & 0.077 & 0.339 \\
\hline G & G & $\mathrm{T}$ & 0.084 & 0.054 & 0.035 \\
\hline A & G & $\mathrm{T}$ & 0.024 & 0.034 & 0.233 \\
\hline $\mathrm{A}$ & $\mathrm{T}$ & $\mathrm{C}$ & 0.022 & 0.019 & 0.674 \\
\hline A & G & $\mathrm{C}$ & $5.6 \mathrm{E}-4$ & 0.000 & 0.576 \\
\hline G & G & $\mathrm{C}$ & $2.9 \mathrm{E}-7$ & $9.2 \mathrm{E}-7$ & 0.969 \\
\hline
\end{tabular}

In this study, we identified the SNPs in $I L-27 p 28$ and analyzed the genotype of these SNPs in asthma patients and non-asthmatic controls. The genotype and allele frequencies of the g. $-964 \mathrm{~A}>\mathrm{G}$ SNP of $I L-27 p 28$ in asthma patients were significantly different from those in the control group (Table 2). This result suggests that the g.-964A $>$ G polymorphism of $I L-27 p 28$ may be associated with susceptibility to asthma. The polymorphisms within the binding site of the promoter region probably influence the expression of $I L-27 p 28$ through a reduced affinity of binding between the transcription factor and its binding site, although we cannot rule out the possibility that multiple genetic alterations also lead to the aggravation of asthma. Our results suggest that these polymorphisms are possibly correlated with susceptibility to allergic or autoimmune responses. The distribution of the haplotype ATT and GGT was significantly different between the asthma patients and healthy controls (Table 5). It is most likely that those people with the haplotype ATT in g.-964A > G, g.2905T > G and g.4730T > C of $I L-$ $27 p 28$ are more prone to asthma than those with the other haplotype. Conversely, those people with the haplotype GGT in g.-964A $>$ G, g.2905T $>$ G and g.4730T $>\mathrm{C}$ of $I L-27 p 28$ would be more resistant to asthma.

Eosinophil is accumulated in high numbers in the lungs of asthmatic patients and is believed to be essential in phagocytosis as well as in the allergic and inflammatory reactions of asthma. Therefore, the number of accumulated eosinophils within the bronchial wall is a characteristic feature of asthma (Humbles et al. 1997). It has been estimated that at least a dozen polymorphic genes regulate asthma by controlling the inflammatory response, $\mathrm{IgE}$, cytokines and chemokines (Cookson 1999). However, our results reveal that the polymorphisms of the $I L-27 p 28$ gene in asthma patients are not closely associated with the level of total serum IgE or with the counts of peripheral blood eosinophil (Table 4). The level of IgE and the accumulation of eosinophil in chronic asthma patients most likely derive from the multiple physiological alterations that eventually lead to a late stage of asthmatic symptoms. 
Taken as a whole, our results strongly suggest that the g. $-964 \mathrm{~A}>\mathrm{G}$ polymorphism of $I L-27 p 28$ could be associated with a susceptibility to asthma. The overexpression of $\mathrm{IgE}$ and eosinophil accumulation are most likely to be late consequences of asthma development. Our analysis of $I L-27 p 28$ polymorphisms is a novel approach that may eventually provide an insight to further functional studies of IL-27p28 in association with other allergic diseases.

Acknowledgements This work was supported by a grant from the Korea Health 21 R\&D Project, by the Ministry of Health \& Welfare (01-PJ3-PG6-01GN09-003).

\section{References}

Abbas AK, Murphy KM, Sher A (1996) Functional diversity of helper T lymphocytes. Nature 383:787-793

American Thoracic Society (1987) Standards for the diagnosis and care of patients with chronic obstructive pulmonary disease (COPD) and asthma. Am Rev Respir Dis 136:225245

Becker C, Wirtz S, Neurath MF (2005) Stepwise regulation of TH1 responses in autoimmunity: IL-12-related cytokines and their receptors. Inflamm Bowel Dis 11:755-764

Chae SC, Park YR, Song JH, Shim SC, Yoon KS, Chung HT (2005) The polymorphisms of Tim-1 promoter region are associated with rheumatoid arthritis in a Korean population. Immunogenetics 56:696-701

Cookson W (1999) The alliance of genes and environment in asthma and allergy. Nature 402:B5-B11

Cookson W (2002) Genetics and genomics of asthma and allergic diseases. Immunol Rev 190:195-206

Cooper AM, Magram J, Ferrante J, Orme JM (1997) Interleukin 12 (IL-12) is crucial to the development of protective immunity in mice intravenously infected with mycobacterium tuberculosis. J Exp Med 186:39-45

Coyle AJ, Wagner K, Bertrand C, Tsuyuki S, Bews J, Heusser C (1996) Central role of immunoglobulin (Ig) $\mathrm{E}$ in the induction of lung eosinophil infiltration and $\mathrm{T}$ helper 2 cell cytokine production: inhibition by a non-anaphylactogenic anti-IgE antibody. J Exp Med 183:1303-1310

Daser A, Meissner N, Herz U, Renz H (1995) Role and modulation of T-cell cytokines in allergy. Curr Opin Immunol 7:762-770

Devergne O, Hummel M, Koeppen H, Le Beau MM, Nathanson EC, Kieff E, Birkenbach M (1996) A novel interleukin-12 p40-related protein induced by latent Epstein-Barr virus infection in B lymphocytes. J Virol 70:1143-1153

Ho IC, Glimcher LH (2002) Transcription: tantalizing times for T cells. Cell 109:S109-S120

Hofstra CL, Van Ark I, Hofman G, Kool M, Nijkamp FP, Van Oosterhout AJ (1998) Prevention of Th2-like cells responses by coadministration of IL-12 and IL-18 is associated with inhibition of antigen-induced airway hyperresponsiveness, eosinophilia, and serum IgE levels. J Immunol 161:50545060

Humbles AA, Conroy DM, Marleau S, Marleau S, Rankin SM, Palframan RT, Proudfoot AE, Wells TN, Li D, Jeffery PK, Griffiths-Johnson DA, Williams TJ, Jose PJ (1997) Kinetics of eotaxin generation and its relationship to eosinophil accumulation in allergic airways disease: analysis in a guinea pig model in vivo. J Exp Med 186:601-612

Kuchroo VK, Das MP, Brown JA, Ranger AM, Zamvil SS, Sobel RA, Weiner HL, Nabavi N, Glimcher LH (1995) B7-1 and B7-2 costimulatory molecules differentially activate the TH1/TH2 developmental pathways: application to autoimmune disease therapy. Cell 80:707-718

Lack G, Renz H, Saloga J, Bradley KL, Loader J, Leung DY, Larsen G, Gelfand EW (1994) Nebulized but not parenteral IFN-g decrease IgE production and normalizes airways function in a murine model of allergen sensitization. J Immunol 152:2546-2554

Larousserie F, Bardel E, Pflanz S, Arnulf B, Lome-Maldonado C, Hermine O, Bregeaud L, Perennec M, Brousse N, Kastelein R, Devergne O (2005) Analysis of interleukin-27 (EBI3/p28) expression in Epstein-Barr virus- and human Tcell leukemia virus type 1-associated lymphomas: heterogeneous expression of EBI3 subunit by tumoral cells. Am J Pathol 166:1217-1228

Miyazaki Y, Inoue H, Matsumura M, Matsumoto K, Nakano T, Tsuda M, Hamano S, Yoshimura A, Yoshida H (2005) Exacerbation of experimental allergic asthma by augmented Th2 responses in WSX-1-deficient mice. J Immunol 175:2401-2407

Mosmann TR, Coffman RL (1989) TH1 and TH2 cells: different patterns of lymphokine secretion lead to different functional properties. Annu Rev Immunol 7:145-173

O'Garra A (1998) Cytokines induce the development of functionally heterogeneous $\mathrm{T}$ helper cell subsets. Immunity 8:275-283

Pflanz S, Timans JC, Cheung J, Rosales R, Kanzler H, Gilbert J, Hibbert L, Churakova T, Travis M, Vaisberg E, Blumenschein WM, Mattson JD, Wagner JL, To W, Zurawski S, McClanahan TK, Gorman DM, Bazan JF, de Waal Malefyt R, Rennick D, Kastelein RA (2002) IL-27, a heterodimeric cytokine composed of EBIS and p28 protein, induces proliferation of naïve CD4(+) T cells. Immunity 16:779-790

Pflanz S, Hibbert L, Mattson J, Rosales R, Vaisberg E, Bazan JF, Phillips JH, McClanahan TK, de Waal Malefyt R, Kastelein RA (2004) WSX-1 and glycoprotein 130 constitute a signaltransducing receptor for IL-27. J Immunol 172:2225-2231

Sprecher CA, Grant FJ, Baumgartner JW, Presnell SR, Schrader SK, Yamagiwa T, Whitmore TE, O'Hara PJ, Foster DF (1998) Cloning and characterization of a novel class I cytokine receptor. Biochem Biophys Res Commun 246:8290

Wirtz S, Becker C, Fantini MC, Nieuwenhuis EE, Tubbe I, Galle PR, Schild HJ, Birkenbach M, Blumberg RS, Neurath MF (2005) EBV-induced gene 3 transcription is induced by TLR signaling in primary dendritic cells via NF-kappa B activation. J Immunol 174:2814-2824 